\title{
A PEACE AND SECURITY STRATEGY IN INTERNATIONAL RELATIONS: THE DIALOGUE BETWEEN THE WEST AND ISLAM
}

\begin{abstract}
ARZU YILMAZ*
ABSTRACT

In the context of building a new foundation for the harmonious continuation of the established world order, religions/cultures/civilizations are now being summoned to the cause of creating peace and security. The dialogue projects which are carried out to serve this goal work to resolve the lack of mutual knowledge among the communities described as "the West and Islam", to discover the common values, and thus to establish some kind of universal understanding. In this article, no distinction is made between the efforts variously described as "interreligious dialogue", "intercultural dialogue", or "the alliance of civilizations". Instead, all these endeavors will be commonly referred to as the "Dialogue between the West and Islam". This is because, in practice, these efforts are all premised upon the idea that Islam constitutes a threat to the universal values which the West represents. This paper argues that dialogue alone will be insufficient to preserve peace and security in a world in which some two billion eight hundred people are living on less than two dollars per day, and a further one billion two hundred million are struggling to stay alive with less than one dollar. One banner that the anti-globalist demonstrators unfurled in Geneva provides a succinct summary of this case: "If there is no justice, there will be no peace."
\end{abstract}

\section{KEYWORDS}

Interreligious Dialogue, Intercultural Dialogue, Alliance of Civilizations

*Arzu Yllmaz, is a PhD Candidate in the Department of International Relations, Ankara University, Ankara, Turkey. 


\section{Introduction}

The world order that we are living with today is, to some significant degree, the child of modernism, which set out with the ideal of creating a universal order based on the principles of freedom, equality and brotherhood. It can be said that modernism was indeed successful in creating a universal order in the form of the capitalist world economy; however, it has come to be widely experienced that this order does not and cannot serve the principles of freedom, equality and brotherhood.

This awareness of failure, the seeds of which were already embedded in the revolutions of 1968, destroyed the most fundamental element of the modernist ideal: the optimism or hope which gave meaning and continuity to the said order. With the destruction of this fundamental element, the structures which had been built upon it started (and continue) to crumble one after another. The result is a period which is universally recognized as a time of crisis by opponents as well as by apologists for the established order.

There is no such consensus, however, when it comes to the question of whether this crisis is going to lead to the self-restructuring of the established order, or to the establishment of an entirely new order. As always happens in periods of social chaos, competing value-systems and ideologies struggle to emerge dominant from the uncertainty. In the most general terms, this struggle takes place between those who have benefited from the established order and those who have suffered from it. In the international relations, the parties of this struggle are explicitly identified as the West and Islam. We will be discussing the reasons for selecting this definition later on. For now, it is enough to emphasize the fact that the basic framework of this definition is religion. On the international stage, religions have been cast in a leading role - a role in which they act as a cause of the actions which threaten the established order, and in which they are invoked as the basis for the harmonious continuation of that order. As the central protagonists in this transitional period, this dual role of religion carries some important clues which might help us to understand the essence of the current struggle.

In the context of attempts to build a new foundation for the harmonious continuation of the established world order, religions are 
now being summoned to the cause of creating peace and security. I should indicate that in this article, no distinction is made between the efforts variously described as "interreligious dialogue", "intercultural dialogue", or "the alliance of civilizations". Instead, all these endeavors will be commonly referred to as "the Dialogue between the West and Islam". This is because, in practice, these efforts are all premised upon the idea that Islam constitutes a threat to the universal values which the West represents. At the same time, these efforts are intended to help overcome the marked fear of Islam (Islamphobia) which is based on this perception of threat and which is increasing across large parts of the West. The dialogue projects which are carried out to serve these goals work to resolve the lack of mutual knowledge among the communities described as 'the West' and 'Islam', to discover the common values, and thus to establish some kind of universal understanding.

At this point it is apposite to underline the fact that, although in the literature of social science 'civilization', 'culture' and 'religion' are each defined as separate concepts, in the context of dialogue projects carried out by the international institutions like the UN and the EU, religion is usually seen as the defining essence of culture and civilization. The Alliance of Civilizations project, for example, through which such efforts are conducted on the inter-state level, defines the two parties of the dialogue as 'the West' and 'Islam', and thus indicates clearly that it approaches Islam as the core and the defining element of the West's interlocutor civilization. In this context, the question of "why not Christian-Muslim Dialogue, rather than the Dialogue between the West and Islam?" may help to shed some light on this article's central subject of investigation.

The main problem with discussions about the aforementioned dialogue efforts can be seen in the immanent struggle between the Euro-centric structure of modernism and the Christian sects. However, even as a paradigm which originates from the unique conditions of European geography and history, modernism nonetheless makes a claim which extends far beyond these limitations: the principle of universality. Now more than ever, the hope that the entire world will progress on the basis of rationality appears less and less feasible; and this calls into question 
modernism's central claim of universality, or illustrates the fact that this principle was actually never valid. ${ }^{1}$

This is why many of the discussions now taking place within this framework define the current crisis as nothing less than the "crisis of modernism" itself. In this article, however, and without denying the problems which result from modernism's Euro-centric claim to be the "one, absolute and universal" proposition, an

\footnotetext{
${ }^{1}$ The critics of modernism were especially developed in the 1970s by European thinkers. Postmodernism, which was born from these criticism led by thinkers like Jean Francois Lyotard and Wittgenstein, in the general terms depends on the questioning of the one unique truth claim of the European philosophy in the post-Enlightenment era. Instead relativity has been preferred and the design of the one, exclusive, objective, external or universal truth was rejected. In this context positivism is a type of colonialism or colonialism is a result of positivism. The postmodernism discussions have a predominant effect especially on preparing the basis for the religions to take stage as political actors. Ali Yaşar Sarıbay analyzes this effect as such: The fact that the Postmodernity decentralizes the subject, allowed important developments like the appearance of the community feeling, the gathering of widespread masses around temporary emotional communities and the invention of a new lifestyle possible. Religions rise upon a community basis, which make the values of that community the foundation of either the lifestyle or the cultural world of which they offer. Therefore, while postmodernity leads the individuals to religion by encouraging the community feeling, it also creates a framework in which religions can represent themselves and/or the religious movements freely. In other words, postmodernism, which permits everyone the right to transform their lifestyle in to a culture, inevitably enforces a structure founded on majority. Like every other lifestyle, religion also legitimizes its situation in the mentioned structure being one of those majorities and having the right to transform their lifestyle in to a culture (Ali Yaşar Sarıbay, Postmodernite, Sivil Toplum ve İslam, İstanbul, Alfa Yayınları, 2001, p. 22).

The side of postmodernism that enables finding the way back to religion becomes so evident that; despite having conflicting political values, while seeking a way to repair the societal reality- worn and torn by modernismsome theorists inevitably come across each other. For example D. Bell, who is a neo-conservative, and F. Jameson, who is a neo-Marxist, meet each other inside the postmodern culture, when making a call for the renovation of religious symbolism for the sake of repairing the societal link (Sarıbay, Ibid., p. 87).
} 
evaluation of the current situation as a "crisis of capitalism" is thought to be more elucidating. This is because, as is mentioned above, the only legacy of modernism which has historically demonstrated its universally applicable nature is the capitalist world economy.

Born from modernism, the capitalist world economy has given new forms to modernist structures over the course of its functioning as an actual historical system. For example, modernism will always reject a domination based on the notion of a transcendental will, ${ }^{2}$ because among the most basic conditions of modernity is secularism. Within the capitalist system, too, secularism is a principle; but religion also remains as a political tool. In the historical development of the capitalist world economy, religions maintain an important functional value as structures which serve the functioning of the system. The analysis that Weber made in "Protestant Ethics and the Spirit of Capitalism" is the clearest evidence of this. ${ }^{3}$ The current

${ }^{2}$ However, Ernest Gellner claims that such kind of a sharp distinction cannot be made between modernism and religion, because the proposition of modernism about the uniqueness of reality is an output of the Christian doctrine: "If a serious, even obsessive, monotheism and oneness had not existed the rational naturalism of the enlightenment philosophy may not have seen the daylight" (Ernest Gellner, Postmodernizm, İslam ve Us [Postmodernism, Reason and Religion], trans. Bülent Peker, Ankara, Ümit Yayıncilik, 1994, p. 137).

${ }^{3}$ In Sociology Durkheim is the first name that has openly made the analysis of the functional relationship between the societies and the religions. Durkheim says that the order and structures of the society find their expressions in religion. The religious rituals makes it possible for the people, who are living in a society, to remember the social "constitutions" of their own structures from time to time. Therefore, Durkheim claims that religion is not a personal but a societal procedure. The respect shown to the religious one, is nothing but a respect shown to the authority, and the real object of religious worshiping is the society itself (Emile Durkheim, Dini Hayatın Illkel Biçimleri [The Elementary Forms of Religious Life], trans. Fuat Aydın, İstanbul, Ataç Yayınları, 2005).

Max Weber analyzes the abovementioned function of religion by focusing on its influence over the development process of capitalism. According to Weber what enabled the development of capitalism is the world view of the Protestantism. In the Calvinist type of Protestantism the belief that the human being is born to earth not to pursue her own aims, but to realize the natural order which God has gifted, has led the people in the capitalist 
centrality of religion on the stage of politics is not, then, a new phenomenon - even if some specific protagonists (such as Islam) are stepping into new roles.

To better understand the new position of Islam, it might be helpful to elaborate on the crisis of capitalism. As Immanuel Wallerstein argues, the functioning of capitalism, which is based on the logic of endless growth and accumulation, is confronted with the stark reality of the limits of the resources and the structures upon which it is built. In consequence the political problems are manifest in the form of specific issues such as the control of the world's natural resources, or the changing patterns of human migration. This deepening crisis is in turn sharpening the impact of structures such as nationalism, racism, and sexism - systems which help to define capitalism's limits of inclusion and exclusion, and to determine the distribution of its surplus value. For example, the focal issue of the EU's security policy is the question of migration. Migrants, who were accepted in a period when there was a need for cheap labor but who can no longer generate the need for further cheap labor, are now demanding a share from the narrowing pool of resources, compelling

\footnotetext{
system to develop the rational sides of the society and by this way motivated them to accept and use the rationality elements of the market mechanism as a reflection of God. The idea of Calvinism that the achieved wealth should not be used for personal interest, has led to the result of added value. However, since success was accepted as a sign indicating that the God loves the human being, the individuals were encouraged to work hard in Calvinism. According to Weber, it was by this protestant ethic that capitalism which started to gain its form, found a platform to further develop on (Max Weber, Protestan Ahlakı ve Kapitalizmin Ruhu [The Protestant Ethic and the Spirit of Authoritarianism: Puritanism, Democracy, and Society], trans. Zeynep Gürata, Ankara, Ayraç Yayınevi, 1999).

Taking off from these findings, Weber uses these expressions to define the relationship between the society and religion: "In reality every religion, influences the people it is applied to by its objectives and promises to a certain extent. However, the next generation searches for the new interpretations of the forecasts of the religions in order to adopt them to the new circumstances. This is how religious thinking becomes compliant with the religious needs" (Max Weber, "Dünya Dinlerinin Sosyal Psikolojisi", Din Sosyolojisi, Yasin Aktay and M. Emin Köktaş (eds.), Ankara, Vadi Yayınlar1, 1998, p. 165).
} 
European states to implement restrictive immigration policies. Closing the doors to new immigrants, Europe has left its existing immigrants with the dilemma of assimilation under the name of integration, or the risk of exclusion. It is within this context that Islam becomes a significant factor, because of its relationship both with the geography of natural resources and with the identity of the immigrant masses.

Despite this crisis, the desire for endless accumulation of capital continues to make itself felt in the capitalist system as an unavoidable reflex action. Recalling the di Lampedusa principle, Wallerstein says that if necessary, in a situation like this, the sovereigns would seek to "change everything in order to change nothing". ${ }^{4}$ According to Wallerstein, in the transitional periods where a historical system ends and a new historical period starts, sovereigns try to invent the change, convincing their supporters to support it while misleading their opponents. Under the guise of allowing or even leading radical change, the sovereigns ensure that nothing will alter their position of privilege. Seen within this framework, the creation of a dialogue between the West and Islam might be perceived as an attempt to manipulate the outcome of the current crisis, giving the illusion of change while actually ensuring that the status quo remains the same. Even the ground on which the dialogue is based - religion - permits of little change; in fact, religions condition their adherents to accept the present world the way that it is, as a creation of God. This attitude is exactly what is required in order to ensure the unproblematic continuation of the present system.

I would like to emphasize the fact that this claim does not imply the rejection of dialogue, which is an essential prerequisite for negotiative democracy. Especially today, when we are standing on the threshold of a new historical system, it is impossible to generate a response to the question; "what kind of a world do we want?" without engaging in dialogue. However, at this point, the question "what kind of dialogue?" gains importance. For example, according to the dialogue type defined as the "ideal speech situation" by Habermas, the free expression of ideas is the most prominent principle. A dialogue based upon this principle will increase mutual understanding

${ }^{4}$ Immanuel Wallerstein, Utopistics or Historical Choices of the Twenty-first Century, New York, New Press, 1998. 
among people. However, this dialogue must remain distant from the exercise and function of power and from the resulting inequalities and discriminations. At the same time, the consequences of this dialogue must not be predefined, nor should any definite results be pursued. In other words, the dialogue should not be premised upon self-interest or strategic outcomes. The participants must be present simply as an empathic audience, meaning that they attain the ability to see the world with the eyes of others. It is only in this way that, although the results may not be definite, a change in the way the participants think can reasonably be expected. ${ }^{5}$

The dialogue efforts which we will be discussing under the name of the dialogue between the West and Islam fall a long way short of incorporating the principles proposed above. First of all, as stated at the beginning, these efforts are largely the product of a peace and security strategy which is informed by political strategy and selfinterest. The intended outcome of this dialogue is already clear: that the existing system, with its spurious claim to universality, will once again be approved and further consolidated, this time through the sanction of the transcendental will. Moreover, a direct relationship of power and discrimination is already established between the parties invited to contribute to this dialogue. The choice to define the parties as "the West and Islam" is the clearest evidence of this.

In an attempt to understand these concerns more fully, let us examine how the Dialogue between the West and Islam has been shaped; how the common understanding that is desired as a result of this dialogue has been structured; and how Islam, qualified as both the subject and the object of this dialogue, has been positioned as the "other".

${ }^{5}$ Jürgen Habermas, A Theory of Communicative Action, Parts I, Cambridge, Polity Press, 1984. 


\section{An International Response to "Temporary Threats and Challenges of Globalization"}

When Samuel Huntington argued, in his 1993 article entitled "the Clash of Civilizations", that the differences between the civilizations which were stuck between the armed forces of a bipolar world during the Cold War were going to cause conflicts in the coming millennium, many social scientists put forward views which attempted to discredit the fundamentals of Huntington's thesis. However, in the years following the publication of this article, institutions such as the UN and the EU started speeding up projects which aimed to promote cooperation and understanding between civilizations, the partnership of cultures, and increased tolerance among religions. These kinds of actions clearly indicate that the possibility of conflict along the lines of civilizational or cultural division was widely acknowledged, and that the categories and lines of division themselves were broadly accepted. ${ }^{6}$

In fact the Parliament of World's Religions, ${ }^{7}$ which first assembled in 1893 in Chicago, launched its second meeting after a

${ }^{6}$ The list of the terrorist organizations of the U.S. Department of State did not include any religious group in year 1980. However, in 1994, 16 out of the 49 terrorist organizations were defined as religious. The following year the number increased; 26 out of the 56 terrorist organizations were defined as religious. When Madeline Albright announced the 30 most dangerous terrorist organizations in the world, the ideological foundation of the half of them were based on religion (Ingmar Karlsson, Din, Terör ve Hoşgörü [Faith, Terror and Tolerance], trans. Turhan Kayaoğlu, İstanbul, Homer Yayinlar1, 2005, pp. 179-180).

${ }^{7}$ The first meeting of the Parliament of World's Religions was held in an important period of the American history. The Protestants, who settled down in North America and established the USA, approached the Catholicism as a degenerated anti-democratic religion that attacks human freedom and individuality. Therefore, in the 1840's, when the first Catholic wave reached America together with the migrants coming from Ireland, the habitants of America firstly referred to them as anti-American. Afterwards this approach caused an enmity towards the Catholics, which from time to time resulted with act of violence like; the sabotage of the Catholic churches in Philadelphia in 1844, homicide of 14 people and conflicts in the streets (Yasin Aktay, “Amerika'da Din-Devlet İlişkileri ve Dinî Cemaatlerin 
century with the support of UNESCO in 1993 at Barcelona. The religious leaders who gathered at this meeting decided that various religions, and especially the monotheistic ones, should be acting collectively in order to solve the problems of the world. ${ }^{8}$

Eleven years later, in 2004, the Parliament of the World's Religions assembled once again in Barcelona with the support of UNESCO to try to address a series of pressing global concerns: the worsening situation of refugees around the world, the burden of debt on developing countries, the prevention of violence, especially violence which is informed by or targeted towards religion, and the water crisis. ${ }^{9}$ As can be seen from the agenda, the world's religious leaders were being quite openly summoned to duty in order to help solve the biggest problems encountered by the world capitalist economy today. But what kind of a solution can be expected from religion or from religious leaders?

Our search for adequate answers to this question will bring us back to the previous discussion of globalization; but before we turn to that field of enquiry (which is addressed below under the heading A Salvation Prescription for Peace and Security) let us first look at what

Etkisi”, Devlet ve Din Iilişkileri-Farklı Modeller, Konseptler ve Tecrübeler, Ankara, Konrad Adaneuer Vakf1, 2003, p. 36).

${ }^{8}$ The Universal Declaration of the Global Ethics that was accepted by the Parliament of World's Religions in the 1993 Barcelona Meeting included these statements: 1) Providing collective action among the religions, especially the monotheistic ones, to solve the problems challenging the world; 2) Achieving the necessary cooperation that will help strengthen the religious and moral values of the societies; 3) Ending the struggles among different religions and cooperating against the ideologies that exclude and despise religions; 4) Cooperating in solving problems like drugs, AIDS, alcoholism, divorce and breaking up of families, ignorance, poverty, hunger, injustice, war and ethnic conflicts; 5) Preventing the use of religion for political or any other kind of earthily objectives; 6) Providing the protection and development of the woman rights, starting from education; 7) Working for the achievement and preservation of the human rights and freedoms, especially the freedom of belief and conscience; 8) Combating with all types of mentalities and evolutions that attempt to restrict any of these rights and freedoms (<http://www.cpwr.org>, 14 February 2009).

${ }^{9}<$ http://www.parliamentofreligions.org/_includes/FCKcontent/File/2004rep ort-rev.pdf>, 14 February 2009. 
is expected from the partnership of monotheistic religions. There is a widely accepted premise that the link between "humans, nature, and the sacred", broken by the modern paradigm, has to be repaired, and the will that is required in order to surmount these problems must be restructured. Again, we can use the approach of international organizations to help us track the ways in which this restructuring will take place. UNESCO, for example, defines the objective of activities conducted under the UN's roof since 1946 as "supporting the dialogue that serves peace". A UNESCO report dated 17 March 2005, however, reveals the shifts in the emphasis of the organization's mission. The main theme of the activities conducted during the years of establishment was defined as "peace in the minds of men"; in time, however, this evolved to become, first, the constitution of common values and understanding in between "people and cultures", and now among the "civilizations". ${ }^{10}$

The year 2001 is accepted as a turning point in the revision of UNESCO's mission. As is widely know, that same year was declared to be the "the Year of Dialogue among Civilizations" by the UN General Assembly. There can be no doubting about the impact of the events of $9 / 11$ on these decisions. The aforementioned UNESCO report from 2005 states quite explicitly that the impact of $9 / 11$ is the central factor behind its renewed support to dialogue between civilizations and its sharpened commitment to projects which prevent the formation of radical or terrorist movements. ${ }^{11}$

In the light of this information we can say that, since 2001, the agenda of the dialogue activities conducted by the UN has been largely determined by the question of "terrorism". While emphasizing

${ }^{10}$ Report by the Directors-General on the Promotion of the Dialogue among Peoples, 171EX/40, Paris, 17 March 2005.

${ }^{11}$ The dialogue activities of UNESCO depend on two decisions. First is the Decision No. 56/6, which foresees the maintenance of peace on the basis of justice, equality and tolerance by eliminating the mutual lack of information among the societies, cultures and civilizations. The second is the Decision No. $31 \mathrm{C} / 39$, which calls for "the international cooperation in the prevention of terrorism". The document used as a reference in this research is taken from the report that was presented by the General Director, responsible for the UNESCO Support of the Interpersonal Dialogue, in the special session held on 17 March 2005 in Paris. 
the importance of dialogue in responding to the "temporary threats and challenges of globalization", the main objective of efforts at dialogue is defined as the discovery of shared universal human values, and the basic approach is one of attempting to counteract the lack of knowledge and understanding which exists between human communities belonging to different religions, cultures, and civilizations. It is hard to avoid the conclusion that, from this perspective, the biggest challenge to world peace and security is perceived to be "terrorism", and that the source of terrorism is understood to be "cultural", or in other words, the "lack of information and respect among the cultures". Dialogue, in this scheme, will help us overcome this lack of understanding and respect, and will therefore provide the means through which we might cease the present conflict and meet at the place of "common, universal, shared" values.

The UN institutionalized the framework, the parties, and the objectives of these dialogue activities in 2005 with the "Alliance of Civilizations Project". It was this initiative in particular which brought the underlying agenda, assumptions, and biases of the longstanding political discussions around civilizations, cultures, and religions into sharp focus. The priority of the Alliance of Civilizations Project was expressed as:

In its initial focus on the relationship between Western nations and predominantly Muslim populations, the Alliance has established priority areas for its programming. These include the political factors that contribute to extremism, the effects of media and education on mutual understanding, and the key population sectors of youth and immigrant communities. ${ }^{12}$

As is clear from this statement, dialogue activities held in the name of peace and security will focus on the relationship between the West and Muslim communities. Expressed another way, the migrant Muslim populations of the West and political Islam are viewed and presented as problems that need to be solved in order to ensure the peace and security both in the West and in the world.

$12<$ http://www.unaoc.org/content/view/79/112/lang,english>, 15 February 2009. 
The traces of this same UN approach may be observed in Europe at a much earlier date. It is widely known that Germany initiated dialogue activities, initially in the educational field, aimed at the integration of the dense Muslim migrant population with the German society in the early 1970s. 9/11, however, transformed the context of such efforts. Germany decided to change the level at which the dialogue is conducted by starting a project called the "EuropeIslam World Dialogue" in 2001, thereby shifting its dialogue programs away from the Ministry of Interior and Culture and towards the arena of international relations. The first action taken by this project was the appointment of new diplomats, responsible solely for the issue of dialogue among religions, to five different countries (Turkey, Yemen, Egypt, Saudi Arabia, and Indonesia).

Gabriel Goltz was one of these diplomats, appointed to work in the Embassy of Germany in Turkey in 2005. He stated that behind the German approach lay the attitude of "something has to be done" - an attitude which came to be widely shared after 9/11. According to Goltz, the issue of Islam had appeared earlier as a factor in internal integration problems (e.g. gender inequality, honor killings etc.), but became an issue of international relations in Germany, as well as in other Western countries, in the post-9/11 era. In a sense we can say that the Europe-Islam World Dialogue Project was a result of Germany's deliberate decision to search for the solution to these problems in the field of cultural origins. As Goltz says, the diplomats, who had been appointed explicitly for this duty, started working to contribute to the foreign policy of Germany:

Our duty as a diplomat is to evaluate the conclusions reached by the intercultural or interreligion dialogues held until now, in a way that makes it possible for them to function as a resource of a political projection. We are trying to see.... what is capable of changing? Is it religion, tradition or culture? ${ }^{13}$

\footnotetext{
${ }^{13}$ The information given with reference to Gabriel Goltz, who worked in the Embassy of Germany in Turkey as the responsible diplomat for the InterReligions Dialogue, is quoted from the notes of the interview held with him on 6 July 2006.
} 
It is evident that this approach not only predetermines the source or origin of the problem, but also anticipates that the solution to these problems lies in the transformation of Muslim societies. A similar approach can be detected in activities which the German government is conducting in partnership with other institutions. For example Frank Spengler, who is the Turkish representative of the Konrad Adenauer-Stiftung institution, summarizes the objective of their mission as follows:

Taking in to consideration the increasingly problematic relationship of Europe with Islam, the issue of "Dialogue with Islam" has for long been one of the most important missions carried out by the KonradAdenauer-Stiftung in the world. In these missions; dialogue is never an end in itself, on the contrary the aim is to eliminate the mutual misunderstanding and the lack of information, as well as to support the reformist movements in the Muslim countries. ${ }^{14}$

As this analysis underlines, even though the framework of the Dialogue between the West and Islam was designed to overcome the mutual lack of information and respect among the two parties, it is still premised upon the idea of reinterpreting Islam and/or bringing Islamic culture into alignment with Western values. In this context it becomes evident that the parties in dialogue are not approached as equals, and that while the West is the subject of the said activity, Islam has become the object of it.

The EU projects, participated in by all the European states as part of the wider Dialogue between West and Islam, reproduce the same hierarchical approach. ${ }^{15}$ As a matter of fact the High Level

${ }^{14}$ Frank Spengler, Türkiye ve Avrupa'da İslam Devlet ve Modern Toplum, İstanbul, Konrad Adenauer Stiftung Yayınları, 2005, p. ix.

${ }^{15}$ The EU made the first decision to start the intercultural dialogue activities among the states in 1993, under the context of the Barcelona Process. However, the meeting held in 2002 at Valencia became a milestone for the said dialogue activities. The EU decided to speed up the actions especially regarding the strengthening of the humanitarian and cultural dimension of the European-Mediterranean cooperation, which were considered to be neglected in the last years. The Anna-Lindh Foundation, which was established in Alexandria in 2005 according to this decision, assembled all the EU dialogue activities under one roof. 
Report presented by the Head of the EU Commission, Romano Prodi, in 2002 about the European-Mediterranean Dialogue argues the conditions of a reliable dialogue in some detail. The report, prepared by academics and intellectuals from both sides of the Mediterranean, includes the following statement:

For the dialogue to be called an achievement and for it to be considered credible/reliable, the participating actors have to share certain basic principles. These principles are; respect, equality, and openness as well as the absence of authority and enforcement. Equality means that the participants are contributing to the dialogue equally and that they are in an equal status. In other words, no actor has a privilege or a representative. The thoughts and recommendations are not evaluated according to military or other power parameters, but according to their own ethics and value. ${ }^{16}$

However, the report underlines the fact that the asymmetric relationship between the two sides of the Mediterranean in economic, social and political terms poses the biggest challenge to the success of this ideal dialogue model:

It is deemed necessary to overcome the inequality between the North (EU) and the South (the Mediterranean side) in order to develop a real dialogue. Structurally there is no equality between the North and the South in the terms of economic, social and political power. In this sense, EU is an area where unification is possible despite the inequalities, unlike the South, where there is regional discrepancy and conflict. It is natural that due to the present inequalities the dialogue in the South does not have successful results like the dialogue in the North. ${ }^{17}$

In the light of these criticisms, the claim that dialogue between the West and Islam might produce a common ground of understanding, where the two parties can compromise and reach harmony, becomes implausible or even irrelevant. Chris Brown even argues that this kind of dialogue amounts to little more than one side assuming the responsibility for reinterpreting the values of the other.

16“2002 Mediterranean Dialogue Work Programme",

<http://www.nato.int/med-dial/2002/mdwp-2002.pdf>, 20 May 2006.

${ }^{17}$ Ibid. 
Moreover, he underlines that without a compelling reason there is no guarantee that the result will be accepted by everyone. ${ }^{18}$

Mark Lynch considers "terrorism" as one of the compelling reasons. According to Lynch, 9/11 and the US reaction to it caused insecurity and violence between the West and the Muslim world, while at the same time highlighting the need for dialogue between the two parties. Because dialogue is presented as the best alternative to radicalism and violence, rejecting it would imply the victory of terrorism, which aims to destroy security and to spread fear. ${ }^{19}$ This, too, reinforces the conclusion that efforts at dialogue have been established within a framework determined by a security-driven political agenda. Helle Malvmig evaluates how dialogue has been transformed into a security strategy by focusing on three main indicators: the publication of alternatives to Huntingdon's conflict theory, the continual emphasis on the urgency and importance of dialogue, and the propagation of the idea that the absence of dialogue constitutes a threat to the future. ${ }^{20}$

At this point we should underline the fact that Huntington's thesis is mentioned in almost every document concerned with the field of dialogue. In most of these documents the claims of the theory are not accepted. Even so, referring to this theory remains useful in almost all attempts to analyze the current security and conflict situation. The important point, however, is the way in which the model of dialogue now being established by governments and international institutions actually reproduces or echoes the same basic analysis. Even projects which purport to refute the theory reveal a tacit acceptance of the lines of division described by Huntington. The clearest proof of this is that the dialogue projects themselves (such as the "Alliance of Civilizations" and/or "Europe-Islam Dialogue") are being named after his theory.

${ }^{18}$ Chris Brown, "Cultural Diversity and International Political Theory: From the Requirement to Mutual Respect", Review of International Studies, Vol. 26, 2000, p. 208.

${ }^{19}$ Mark Lynch, "Transnational Dialogue in an Age of Terror, Global Society, Vol. 19, 2005, p. 11.

${ }^{20}$ Hele Malmvig, "Security through Intercultural Dialogue? Implications of the Securitization of Euro-Mediterranean Dialogue between Cultures", Mediterranean Politics, Vol. 20 (3), 2005, p. 351. 
These projects offer no response to the question "how can a dialogue possibly be successful, when the perception of a "threat" to security is directed at one of the parties (Islam) in the dialogue itself?" However, since the real objective of dialogue between the West and Islam is not to strengthen the culture but to create a culture to strengthen the security, it can be said that this state of inequality is neglected.

If we consider institutions like the $\mathrm{UN}$ or the $\mathrm{EU}$ to be international instruments to uphold the functioning of the capitalist world economy, we can see that this situation is unavoidable. The continued security of both organizations depends upon the preservation of the existing system. The fact remains that this zerosum system, in which the winner can win only if someone else loses, and in which the winners are conditioned to ask for more and more, resulting in $85 \%$ of the world's resources being owned by about $15 \%$ of the world's most privileged people, is simply not sustainable.

The dilemma of institutions like UN and EU is that they are faced with the contradictory demands of the existing system, while simultaneously dealing with the problems caused by the inequalities which inevitably result from it. The scarcity of the world's resources forces a change. Some of the initiatives proposed by these institutions reveal that they, too, are aware of this need for change; and yet they continue to search for solutions not in the infrastructure but in the superstructure of the current system.

In this search for a solution the notions of religion, culture, and civilization, which build the "meaning of life" for inhabitants, are being called to duty. As the current system lost the sense of meaning, human communities can have no will to preserve the status quo. In other words, the creation of a more widely shared sense of meaning is urgently required if the existing system is to continue functioning.

\section{A “Salvation Prescription" for Peace and Security}

Peter Wagner emphasizes the creation of congruence among social identities, political limits, and social practices as a precondition for the construction of a political movement. The practices which 
human beings share with others, and which therefore they would like to regularize in society as a whole, will become institutionalized or normalized only when enough people form a union around specific values, and around the extension and influence of those values. ${ }^{21}$

The final period of the capitalist world economy is creating different political actors and different power relationships in accordance with the process of globalization which is triggered by the flow of condensing capital, people and technology. This same process generates inequality and social dislocation, making it extremely difficult to establish the political preconditions which are essential to the harmonious functioning of the order. An example of this may be seen in the problems caused by economic and political decisions taken by major capital owners - decisions which undoubtedly benefit those who take them, but which rarely serve the interests of anyone else.

In this context, the values of liberal democracy and the free market economy, which have been presented over the past twenty years almost as a "salvation prescription", are now facing considerable resistance. While this formula is perceived by neoliberals as a universally applicable remedy which guarantees the elimination of poverty, hunger and misery, its opponents characterize it as little more than camouflage for the destructive invasion of the world by international capital which is transforming the world into "one village", "one world".

Gellner sees this as the natural result of America's defining influence on globalization. At the root of the American attitude lies the absolutization of its own culture and the identification of the entire human situation with it. America, therefore, approaches other cultures as a deviation from the one universally true and valid human situation. According to the Americans, features like individualism, equality, freedom, and constant innovation are part of the air that they breathe; having never lived in any other social or ethical climate,

${ }^{21}$ Peter Wagner, Modernliğin Sosyolojisi: Özgürlük ve Cezalandırma [A Sociology of Modernity: Liberty and Discipline], trans. Mehmet Küçük, İstanbul, Sarmal Yayınları, 1996, p. 266-267. 
Americans are blind to the absence of these features (or the demand for them) in other cultures. ${ }^{22}$

Arguments about modernization, many of which focus on Islam, are shaped by this premise. To the extent that Islam acts as source of "terrorism, which is the biggest challenge facing the preservation of peace and security in the world" it signifies the "deviation from the true human situation". In order to surmount this obstacle, a revision is deemed necessary to those Islamic tenets which exclude liberal democracy or which are perceived as the inspiration for terrorism. It can be argued that the homogenizing effect of globalization is only possible if those regions and cultures that are furthest from the dominant global influence share the same basic frame of reference as the center which actually produces the exported object, theory, concept, system or structure in the first place. For cultures within the Muslim geographical sphere, for example, to even receive the messages sent by the global center they must first absorb and assimilate that center's framework of understanding the world. ${ }^{23}$

As a result of this, tension has been caused by the failure of the globalization process to produce the expected monotypes and by its opposing tendency to cause pluralism. ${ }^{24}$ In this environment, the question emerges regarding how to generate that degree of unity and shared interest which is imperative for the maintenance of the system. Since the system has not been successful in creating unity around the principles of freedom, equality and brotherhood, but is still dependent on some kind of unity to guarantee its survival, where might it turn next in search of a solution?

Those seeking an answer to this dilemma will sooner or later have to look at the issue of religion, especially in an environment where Islamic terrorism threatens peace and security. There are

${ }^{22}$ Gellner, Postmodernizm, İslam ve Us, p. 80.

${ }^{23}$ Thomas Friedman, "Küresel Sistem, Küreselleşme ve Modernliğin Parametreleri”, Postmodernizm ve İslam; Küreselleşme ve Oryantalizm, A. Topçuoğlu and Yasin Aktay (eds.), İstanbul, Vadi Yayınları, 1996, p. 93.

${ }^{24}$ Roland Robertson, "Toplum Kuramı, Kültürel Görecelik ve Küresellik Sorunu", Kültür Küreselleşme ve Dünya Sistemi [Culture, Globalization and the World-System], Anthony D. King (ed.), trans. Gülcan Seçkin and Ümit Hüsrev Yolsal, Ankara, Bilim ve Sanat Yayınları, 1998, p. 101. 
several characteristics of organized religion which might be deployed or exploited in order to consolidate and perpetuate existing systems. First, religions are the strongest and most widespread structures which accept what exists without question and without thought of change. Second, religions encourage hope for a better life to be deferred to the realm of the eternal. The monotheistic religions especially, with their insistence on a single, absolute, constant reality, lend themselves towards the perpetuation of the status quo.

Religion permeates almost every aspect of culture and society, and as such it has never been extricable from politics. Robertson underlines that, in according with a Durkheimian analysis, societies which have a state organization approach religion as an important aspect of their national identities, with different degrees of consecration and deep identity application. ${ }^{25}$ On the other hand, for millions of people religion functions as a kind of organizational infrastructure and as a means of political participation. For example, black communities in the USA used the churches as a place of expression, inspiration, organization, solidarity, analysis and recruitment during the civil rights movement. In this respect, religion can be seen as a means to consecrate the shared American lifestyle in the USA.

Religions generate discourses which encompass all humanity, and make moral and social assertions which claim to be universally applicable. Areas of the globalization process which are of concern to organized religions, and upon which religion will confer their approval or rejection, include: types of values, mentalities and attitudes that should be taught to new generations in the modern world; the ways in which the public is informed about the modern world; the operation of social control mechanisms in society; ethical questions to do with the maintenance of a healthy and peaceful social life; the demonstration of respect and love to all, regardless of ethnic or religious grouping; societal deterioration and collapse as a problem which affects all society's members; the notion that good citizenship

\footnotetext{
${ }^{25}$ Roland Robertson, "Globalleşme, Politika ve Din", Dinî Araştırmalar, Vol. 6 (17), Eylül-Aralık 2003, pp. 362-368.
} 
is a requirement of faith, and even a form of devotion according to certain beliefs and doctrine. ${ }^{26}$

In this framework the problems caused by the capitalist world economy (environmental pollution, for example, or the gulf among the income levels within societies, or poverty and hunger) are accepted as common problems of human kind and thus become subject to universally accepted strategies and action plans. ${ }^{27} \mathrm{We}$ are reminded of the possible contribution of Islamic Humanism, for example, by the model of Izzeddin Abdüsselam, the regulator of 13th century Sharia, who produced a bill on animal rights and nature based upon Islamic law. ${ }^{28}$ In this document Islam is described as "a meaningful civilization, which knows what is aimed for ethically, environmentalist in spirit and humanist in inspiration, existing in the privacy of more than one billion people". ${ }^{29}$

At this point it can be said that Islam, which, as has been discussed, is generally positioned as the object of the dialogue between the West and Islam, is being mobilized by religious leaders and intellectuals to fulfill a duty which is predetermined by the very framing of the analysis. This mobilization is carried out by the said parties within a pattern of assumptions and motivations which goes something like this: the reason behind the current global crisis is that until now the West thought of itself as being self-sufficient; Islam is a unique resource to overcome this crisis; in order for this to happen a modernization movement within Islam is necessary, however this modernization must be an alternative type of modernization; Muslim societies are anyway in need of new interpretations that are in alignment with the requirements of the age; and that, in conclusion,

${ }^{26}$ Durmuş Tatlılığlu, "Küreselleş̧e-Din İlişkisi”, Dinî Araştırmalar, Vol. 6 (17), Eylül-Aralık 2003, pp. 185-193.

${ }^{27}$ Hasan Onat, Türkiye'de Din Anlayışsında Değişim Süreci, Ankara, Ankara Okulu Yayınları, 2003, p. 144.

${ }^{28}$ Richard Langhorne, Medeniyetler Çatışmasından Diyaloğa, İstanbul, Gazeteciler ve Yazarlar Vakfı Yayınları, 1999, p. 135.

${ }^{29}$ Tarık Ramazan, İslam: Medeniyetlerin Yüzleşmesi: Hangi Modernite için Hangi Proje [Islam, le face à face des civilisations. Quel projet pour quelle modernité?], trans. Ayşe Meral, İstanbul, Anka Yayınları, 2003, p. 319. 
these efforts will combine to counteract the perception of Islam as a "threat". 30

In the ongoing dialogue between the West and Islam, in which universities and non-governmental organizations are taking an active part (alongside internationally institutionalized structures like the UN and the EU), the main target audience is the young population. It is noticeable that in many of these dialogue initiatives exchange programs for young people are the dominant mechanism for the facilitation of dialogue. It seems irrefutable that this is a suitable method, and one which fits the dialogue type defined by Habermas as the ideal speech situation. However, when we examine the discourse within which this method is being utilized, we find important clues about what is meant by the dialogue between the West and Islam. Take, for example, the symbol of Prophet Abraham, who is often utilized in these dialogues in order to emphasize commonalities: ${ }^{31}$

${ }^{30}$ To the arguments held around Islam and modernity, the critics like Islam can not comply with democracy, are responded as such: "What is the basic concept? Either Christianity or Islam, in the basis of both the human being is a sacred creature. The religion centers on the person, the human being. Also democracy centers on the individual. This means that there is compatibility among Islam, Christianity and democracy. Moreover, if the procedure of the contemporary democracy is analyzed, the similarities with the elements like şûra, meşveret, icma (council, consultancy) of Islam can be observed. Therefore one of the main points, which should be expressed, is that Islam is compliant with the contemporary democracy in the basics. If this democracy is not being practiced in the Muslim countries, the reasons for this should be mentioned. What are the reasons for this? The sultanates, sheiks, this and that, which are established in defiance of the basic elements of Islam, in other words; the autocratic civil orders/polities. In Islam neither kingdoms nor sultanates exist. They were compulsorily adapted to Islam after the $11^{\text {th }}$ and $12^{\text {th }}$ centuries. However, in the spirit of Islam these things do not exist. We should be clarifying this. If we are to clarify this we can eliminate the baseline of the ideological gun pointed to Islam" (Kemal Karpat, Savaş ve Demokrasi, İstanbul, Gazeteciler ve Yazarlar Vakf1 Yayınları, 2004, p. 145-146).

${ }^{31}$ The Symposiums on "Following the Prophet Abraham", which the first is organized in 2000 and, the second is organized in 2003, also known as the "Harran Meetings" in Turkey, can be seen as an example of this. These symposiums were conducted by the Intercultural Dialogue and Cooperation Platform (KADIP) known as an organization of the Fethullah 
The young people should understand that the absurdity exists in blindfold rejection of the authority as much as it does in obedience without questioning. Obedience in a true authority does not damage the person's individuality; on the contrary it provides the development of human capabilities that are distinctive of her...The model of Abraham can teach the young people what obedience, courage, moving towards future with hope and the true belief of one God really means. What we should do is -just like Abraham successfully did -; to leave the decision to the hands of God, who knows everything the best. $^{32}$

The obedience which is stressed here as the greatest virtue clearly stands in opposition to the central inheritance of Enlightenment thinking: the idea that the world can and should be understood through rational human enquiry, and not through revelation of the transcendental will.

The failure of some of the ideologies which were developed within this same rational tradition and which were for so long presented as "salvation prescriptions" is used as a justification for this rejection. Democracy itself, however, is not rejected or abandoned; rather, the argument is made that, so long as democracy rests on "a political and cultural framework that breeds from ethical and moral origins", then religion and democracy do not contradict one another. In this context it is emphasized that "since power defines law, law cannot be seen as the only resource of legitimacy". The pursuit of peace and security provides an example of what this might mean in practice: in order to prevent war, it is necessary, through education, to promote a mentality of conciliation and the pursuit of peaceful ends. Since rationality, it is claimed, is not able to designate such objectives on its own terms, this education will need to be informed by traditionally rooted (i.e. religious) ethics. A specific example of this might be the use of the Islamic tradition on the discipline of human desires and acquittals.

Gülen Community. For detailed info see, 〈http://www.gyv.org.tr>, 14 Februaray 2009.

32Jules Janssens, “İbrahim’in Rehberliği’nde Hoşgörü Sahibi Bir Nesil Yetiştirmek", Hazret-i İbrahim'in İzinde, Cemal Uşak (ed.), İstanbul, Gazeteciler ve Yazarlar Vakfi, 2001, p. 226-235. 
In the current situation, then, the discourse which dominates the dialogue between the West and Islam foresees that universal law should restructure its legitimacy using ethical values based on religion. There are two main reasons behind this attitude: firstly, the regulations of universal law have been adopted by such a majority in the world, and no religion can deny something which has gained acceptance on such a scale; and secondly, many of these regulations are already requirements of religious ethical codes. ${ }^{33}$

In the final analysis the view of the capitalist world economy, which defines individuals and societies within a hierarchical relationship and which sustains these hierarchies, is aligned with and supported by the traditional outlook of religions, which perceive and legitimize the social order as an integral part of the universal and divine order. As a consequence, the system of global capitalism can expect to receive from the religious establishment an endorsement or an approval grounded in ethical claims. Conversely, and with some irony, religions have found their social role and reputation strengthened by institutions which are an integral part of the secular, modernist inheritance.

${ }^{33}$ One of the most discussed themes is that the enforcement power of modern law is in need of an ethical training. For example the "Explanation of Universal Ethics" by Hans-Küng, who is accepted as a doyenne in the field of interreligious dialogue, is one of the most typical examples of this attitude: "We have learnt from our personal experiences and the history of our planet full of constraints that a better world order is not established only by laws, regulations and traditions. Neither can it be established by force. The success of achieving the preservation of the peace, the justice and the earth depends on the agreement and cooperation of people on the achievement of justice. A contribution to the realization of justice and freedom requires responsibility and task consciousness, and for this both the hearts and the minds of the people should be addressed. Without an ethical behavior a foundation that will provide the maintenance of law will not become reality. Therefore, without a universal order there can not be a new world order" (Hans Küng and Karl-Josef Kuschel, Evrensel Bir Ahlaka Doğru [A Global Ethic: The Declaration of the Parliament of the World's Religions], trans. N. Aşıkoğlu and Tosun Doğan, Ankara, 1995, p. $15)$. 
Despite the fervent hopes of some, this process of mutual reinforcement will not be enough to overcome the crisis which is now engulfing the system. This is because the system of global capitalism, in denial of the fact that its own inherent structures are the root cause of the present crisis, is still hoping that a blessing by those institutions which claim to speak for a transcendental power will be enough to ensure its survival. What is required, however, is not the consecration of the existing order by the religious establishment, but a fundamental and structural transformation of that order. Religions, which cannot accommodate the basic assumption that the world can be transformed by human action, do not lead such changes. Current efforts at dialogue between the West and Islam, therefore, can be understood as attempts to strengthen rather than to challenge a fundamentally flawed and failing system.

\section{Conclusion}

The dialogue between the West and Islam, implemented globally in order to preserve peace and security, is a manifestation of a wider attempt to overcome the crisis which the capitalist world economy is now going through. Though this claim may seem deceptive, if we consider the fact that the preservation of this economic system is regarded as the foundation of global peace and security - an assumption which underpins almost all activity in the field of international relations - the validity of this thesis becomes apparent.

International institutions will not and cannot lead a more sweeping effort to change the structure of the system itself, which is the ultimate cause of the current crisis. However, they will be prepared to manage, accommodate, and manipulate change and the appearance of change in the interests of preserving the underlying system and the privileges which it confers upon them.

The dialogue between the West and Islam is one foundation upon which change, demanded by the systemic crisis, may be manipulated in the interests of the capitalist world economy. The structure that is then built upon this foundation legitimizes the role of religion in the public sphere. As was emphasized above, the apparent reason behind this politic preference is to diffuse the global 
opposition that arises in opposition to the functioning of the capitalist system and the inequalities created by it. In this attempt to neutralize potentially decisive opposition, the power of religion is being deployed in order to induce in entire populations a passive and fatalistic acceptance of the world and the universe as it is.

What will be the effect of a political strategy which uses Islam as the object of dialogue with religion itself, and with the nations of the Middle East which view Islam as a source of ideological reference? It is too early to give an adequate response to this question. However, we can already say that one of the methods adopted in order to combat radical Islam is the invention and promotion of a moderate Islam model. We will have to wait and see how (and whether) the dialogue between the West and Islam helps this model to find acceptance in the Middle East.

What we can conclude at the present time with some confidence is that, in a world in which some two billion eight hundred people living on less than two dollars per day and a further one billion two hundred million are struggling to survive on less than a dollar, dialogue along will not be enough to ensure peace and security. One banner unfurled at the recent protests in Geneva provides a succinct summary of this case: "If there is no justice, there will be no peace". 